\title{
Effects of coffee management intensification in natural forests on woody species diversity and structure in Yayo district, south western Ethiopia
}

\author{
Fikiru Gamachu and Tefera Jegora* \\ Department of Forestry, Bedele College of Agriculture and Forestry, Mettu University, Bedele, Ethiopia \\ Received 01 March 2019, Accepted 02 May 2019, Available online 04 May 2019, Vol.7 (May/June 2019 issue)
}

\begin{abstract}
This study was conducted to evaluate the difference between woody species diversity, structure and similarity in natural forests and adjacent coffee farms in Yayo district, southwestern Ethiopia. Vegetation data were collected from both land use systems using transects walk lines. The Shannon, Simpson's, similarity and importance values index were analyzed using SPSS version 20 software. The result revealed 64 woody species belongs to 31 families from both land uses. Moraceae had the most diverse family having each 5 and 8 species in coffee farms and natural forests respectively. The species richness was higher in natural forests (54) than coffee farms (38). Coffea arabica (42.85\%) and Celtis africana (21.14\%) those frequently occurred had the highest importance value indices in coffee farms and natural forests respectively. Of total species recorded, 28 (43.75\%) are common, 26 (40.63\%) and 10 (15.62\%) were unique to natural forests and coffee farms respectively. The highest number of woody plants per hectare were distributed in diameter at breast height $5-10 \mathrm{~cm}$ having $1250 \mathrm{ha}^{-1}$ (64.10\%) in natural forests and $471 \mathrm{ha}^{-1}$ (72.33\%) in coffee farms. The total basal areas were 364.44 and $669.84 \mathrm{~m}^{2} \mathrm{ha}^{-1}$ in coffee farms and natural forests respectively. The result indicated that planting coffee in natural forests with intensified management system causes significant differences on the overall woody species diversity i.e. the structure, composition and regeneration rates of the forest. Therefore, it is recommended to plant coffees in home garden and open lands with planting multipurpose shade trees rather than cultivating it in natural forests.
\end{abstract}

Keywords: Diversity, natural forest, woody species

\section{Background}

Natural forest is one of the richest ecosystems in plant species diversity and used as a home of many and diversified plant species. It has wide ecological and environmental values and is a source of biodiversity (Kitesssa, 2015). Although coffee agro-forestry system is widely seen as the means that can reduce the impacts of deforestation, expansion of unmanaged coffee cultivation is one of the causes of deforestation and biodiversity loss (Ambinakudige and Sathish, 2009). Shaded coffee production system has received considerable attention from conservation organizations in recent years in which it supports more biodiversity and cash income generation from the sale of both timber and non- timber forest products (Gordon et al., 2007). The south west Ethiopian moist evergreen forests are the center of origin for Arabica coffee and where still it is grown and harbor a high frequency of its wild populations. The local people living adjacent or in these forests are traditionally manage

*Correspoding author's ORCID ID: 0000-0003-1458-5962

DOI: https://doi.org/10.14741/ijmcr/v.7.3.4 them for coffee production. The predominant traditional coffee production systems in south-western Ethiopia are the forest coffee (FC) and the semi-forest coffee (SFC) systems, but in areas where there is high population density, intensive forest management to maximize coffee production resulted in a more degradation of the composition, structure and regeneration of forests mainly the woody species diversity (Kitesssa, 2015).

Famers in Ethiopia in general and the south western parts of the country in particular is usually well known by Arabica coffee expansion and management in the evergreen natural forests. But this coffee farm and management practices in these natural forests is not in view of enhancing tree species diversity, structure, composition and regeneration. Yayo is among the potential areas for natural forest in the south western regions which was registered under UNESCO (United Nations Educational, Scientific and Cultural Organization) as one of world biodiversity hotspot area. The Yayo forest is surrounded by the farmers whose socio-economic activities mainly dependent on agriculture. The farmers adjacent to this forest illegally intervene in to this forest through different activities mainly semi-forest coffee 
planting with intensified management for the sake of maximizing coffee production on the transition and buffer zones since long period of time. In doing so, the woody species diversity, structure and the regeneration rate of the forest as well as area coverage of this forest were continuously affected. However, the concerned bodies (the researcher, experts, and government bodies) passively observe and are not well aware of how semiforest coffee plantation affects the species diversity or regeneration rate of the forest and rather they perceived as a means of forest conservation. Because, the effects of coffee planting and its management intensification on the woody species diversity, and structure was scientifically not studied in this area so far. Therefore, this study aimed to investigate the differences between woody species diversity and structure in natural forests and the adjacent management intensified coffee farms and put baseline information for further research and recommended for the alternative cultivation site rather than the natural forests.

\section{Materials And Methods}

\section{Description of the Study Area}

The study was conducted in Yayo district, which is located in Ilu Ababor Zone, southwest Ethiopia. The district is located between $8^{0} 21^{`}-8^{0} 26^{\prime} \mathrm{N}$ and $35^{\circ} 45^{\circ}-36^{\circ} 03^{\circ} \mathrm{E}$. The landform changes frequently from flat surfaces on the top of plateau to very steep slopes and valley bottoms within short distances. The altitudes in the study area range between $1200 \mathrm{~m}$ at lower river valleys to $2000 \mathrm{~m}$ a.s.l. The mean annual temperature is about $20 \& 8^{\circ} \mathrm{C}$. There is some variation in temperature throughout the year, with the hottest months in February to April $\left(29^{\circ} \mathrm{C}\right)$ and the coldest months during July to September $\left(12^{\circ} \mathrm{C}\right)$. The mean annual rainfall is $2100 \mathrm{~mm} \mathrm{year}^{-1}$, with high variation from year to year, ranging from about 1400$3000 \mathrm{~mm}$ year $^{-1}$. The rainfall pattern is uni-modal, with a dry season between November and February and then gradually increasing to the rainy season between May and October (Tafesse, 1996; Tadesse et al., 2002).

\section{Sampling Techniques}

For this study, two land use types namely natural forest with coffee farm expansion and management intensification, and the natural forest without coffee farm were purposively selected to compare their woody species diversity conservation, composition and structures. The two land uses were adjacent to each other in stratified manner in the order of natural forest with and without coffee farm and were taken from almost similar slope ranges following FAO 2006 slope classification criteria. Stratified sampling technique was employed for sample data collection from each land uses. A systematic sampling technique also applied to locate the sampling plots.

\section{Woody Species Inventory}

To study the similarity, structure and diversity of the woody species in the two land uses, three transect line were established with $200 \mathrm{~m}$ intervals and the length of each transect line was $1320 \mathrm{~m}$ and on each transect walk line 12 quadrate size of $10 * 10 \mathrm{~m}$ were employed for adjacent natural forests with $100 \mathrm{~m}$ intervals between each quadrats. The quadrates size of $20 * 20 \mathrm{~m}$ were employed for coffee farms following the same sample technique with varying transect line due to fixed size of coffee farms. A total of 72 quadrats (Sample plots) were taken for both land uses and the data were thoroughly collected. All woody species DBH (diameter at breast height) $\geq 5 \mathrm{~cm}$ in the main plots were identified and measured using caliper at breast height $(1.3 \mathrm{~m})$ (Mac Diken, 1997). Woody species diameter beyond caliper level was measured using meter tape and converted. Woody species with $\mathrm{DBH}<5 \mathrm{~cm}$ were identified and counted in sub-plots of $1 \mathrm{~m} * 1 \mathrm{~m}$ following (Hernandez et al., 2004) techniques in natural forests. On the coffee farms, due to low density of woody species, use of large plot was necessitated. Accordingly, plots of $2 m * 2 m$ were taken from the main plots of $20 \mathrm{~m}^{*} 20 \mathrm{~m}$ at the center. The woody species present in the study area was first identified by their local name in Afan Oromo and their scientific name in the field using researcher's former experiences. For species difficult to identify in the field, plant specimens were collected and identified using useful trees and shrubs for Ethiopia (Azene, 1993).

\section{Data Analysis}

To compare the woody species diversity, structure, similarity and importance values of the sampled land uses; Shannon, Evenness, Simpson, similarity, importance value indices and basal area were calculated for both land uses. The collected data were analyzed using simple descriptive statistics and SPSS version 20 .

\section{Results and Discussion}

\section{Woody species richness and abundance}

A total of 64 woody species belongs to 31 families were recorded from the two land uses. Moraceae had the most diverse having each 5 and 8 species respectively, in coffee farms and adjacent natural forests (Appendix 1). Species richness was higher in adjacent natural forests (54) than in coffee farms (38) (Table 1). The result was in line with the study made by Ambinakudige and Sathish, (2009) where higher species richness was recorded in sacred forest than coffee farms (redeemed and unredeemed coffee plots). The study conducted by (Tadesse, 2003; Feyera and Denich, 2006) in the southwest Ethiopia also indicated that natural forests had higher number of species than semi forest coffees. Mean woody species richness in the coffee farms was significantly $(P<0.05)$ 
lower than in the natural forests (Table 1). This difference is the result of intensive management practices in coffee farms in order to increase the production and productivity of coffee crops. Similarly, Kitessa (2015) stated that coffee farm management intensification resulted in a dramatic reduction in tree species richness, accompanied by a degraded forest canopy structure. Hence, the continuous removal of the seedlings and saplings in the forest with intensified coffee management inhibited the regeneration rates of the forest and causes the dominance of large trees with less diversity. The individual woody abundance recorded showed higher number in natural forests than coffee farms, but not significantly different at $(P<0.05)$ confidence interval (Table 1).

Table 1: Mean (STD) woody species richness and abundance per plot of the study area land use types

\begin{tabular}{ccccc}
\hline \multirow{2}{*}{ Land Use Type } & \multicolumn{2}{c}{ Richness } & \multicolumn{2}{c}{ Abundance } \\
\cline { 2 - 5 } & Total & Mean( \pm STD $)$ & Total & Mean( \pm STD) \\
\hline Coffee farm & 38 & $7.44^{\mathrm{a}} \pm 3.26$ & 657 & $36.44^{\mathrm{a}} \pm 12.64$ \\
Natural Forest & 54 & $11.94^{\mathrm{b}} \pm 2.62$ & 727 & $40.39^{\mathrm{a}} \pm 17.72$ \\
\hline
\end{tabular}

Mean with different letter in the column was significantly different and the same letter was not significantly different at $L S D(P<0.05)$

\section{Frequency and Importance value index}

Coffee (Coffea arabica) had the highest (100\%) frequency occurrence followed by Albizia grandibracteata (61) and Ehretia cymosa (50) whereas, 12 woody species were shown less (6\%) frequency occurrences in coffee farms. In natural forests, Celtis africana and Coffea arabica each having (78\%) shown highest frequency occurrences followed by Dracaena fragrans (72\%), Argomuellera macrophylla (61\%) and Grewia ferruginea (61\%). Unlike the other most frequent woody species, 16 species contributed less frequency (each $6 \%$ alone) in this land use. The importance value index (IVI) measures the overall importance of species and gives an indication of the ecological success of species in a particular area (Molla and Asfaw, 2014). Coffea arabica which is frequently occurred has got the highest importance value indices (42.85\%) followed by Albizia grandibracteata, Albizia gummifera and Ehretia cymosa in coffee farms. More than half or twenty woody species contributed less than $1 \%$ importance value in this land use. In natural forest, Celtis africana (21.14\%) followed by Argomuellera macrophylla, Dracaena fragrans and Albizia grandibracteata were relatively shown the highest importance value whereas thirty one individual species recorded with lowest importance.

\section{Diversity indices}

The Shannon diversity $\left(H^{\prime}\right)$, Species evenness (E) and Simpson diversity index (D) were highest for natural forests than coffee farms. The Shannon index values were higher in natural forests (3.07) than coffee farms (2.13). The value usually lies between 1.5 and 3.5, although in exceptional cases, the value can exceed 4.5 (Kent and Coker, 1992). Species evenness for adjacent natural forests and coffee farms were 0.77 and 0.58 respectively (Table 2). Evenness (E) is normal between 0 and 1 , and with 1 representing a situation in which all species are equally abundant or perfect evenness and vice versa (Kent and Coker, 1992). Similarly, Simpson diversity index value were (0.92) and (0.70) in natural forests and coffee farms respectively (Table 2 ). Thus, there was more diverse species in natural forests than coffee farms hence, Simpson diversity index ranges in value from 0 (low diversity) to a maximum of $(1-1 / S)$, where $S$ is the number of species (Krebs, 1985). Generally, the mean plot level Shannon, Evenness and Simpson diversity indices of natural forest were significantly different at $(P<0.05)$ from coffee farms (Table 3).

Table 2: Overall Shannon, Evenness and Simpson diversity indices of woody species of the study area at land use type

\begin{tabular}{c|cccc}
\hline \multirow{2}{*}{$\begin{array}{c}\text { Land use } \\
\text { type }\end{array}$} & $\begin{array}{c}\text { Number } \\
\text { of } \\
\text { Species }\end{array}$ & $\begin{array}{c}\text { Shannon } \\
\left(\mathbf{H}^{\prime}\right)\end{array}$ & $\begin{array}{c}\text { Evenness } \\
\text { (E) }\end{array}$ & $\begin{array}{c}\text { Simpson } \\
\text { (D) }\end{array}$ \\
\hline $\begin{array}{c}\text { Coffee } \\
\text { farms }\end{array}$ & 38 & $\mathbf{2 . 1 3}$ & $\mathbf{0 . 5 8}$ & $\mathbf{0 . 7 0}$ \\
$\begin{array}{c}\text { Natural } \\
\text { forests }\end{array}$ & 54 & $\mathbf{3 . 0 7}$ & $\mathbf{0 . 7 7}$ & $\mathbf{0 . 9 2}$ \\
\hline
\end{tabular}

Table 3: Mea (+STD) of Shannon, Evenness and Simpson diversity indices of woody species per plot of the two land use

\begin{tabular}{cccc}
\hline $\begin{array}{c}\text { Land use } \\
\text { type }\end{array}$ & $\begin{array}{c}\text { Shannon }\left(\mathrm{H}^{\prime}\right) \\
\text { Mea }( \pm \text { STD) }\end{array}$ & $\begin{array}{c}\text { Evenness (E) } \\
\text { Mea }( \pm \text { STD })\end{array}$ & $\begin{array}{c}\text { Simpson (D) } \\
\text { Mea }( \pm \text { STD })\end{array}$ \\
\hline $\begin{array}{c}\text { Coffee farms } \\
\text { Natural }\end{array}$ & $1.31^{\mathrm{a}} \pm 0.59$ & $0.66^{\mathrm{a}} \pm 0.23$ & $0.58^{\mathrm{a}} \pm 0.25$ \\
$\begin{array}{c}\text { forests } \\
\text { Overall } \\
\text { mean }\end{array}$ & $2.05^{\mathrm{b}} \pm 0.33$ & $0.83^{\mathrm{b}} \pm 0.09$ & $0.81^{\mathrm{b}} \pm 0.07$ \\
& $\mathbf{1 . 6 8} \pm \mathbf{0 . 4 6}$ & $\mathbf{0 . 7 5} \pm 0.16$ & $\mathbf{0 . 7 0 \pm 0 . 1 6}$ \\
\hline
\end{tabular}

Different letters $(a, b)$ in the column indicated that there were significantly different at $L S D(P<0.05)$

\section{Similarity indices}

Based on the presence-absence of the species, the similarity index of woody species between the two land use types was calculated. Out of the 64 woody species recorded, 28 (43.75\%) are common, 26 (40.63\%) and 10 (15.62\%) were unique to natural forest and coffee farm respectively. Accordingly, the calculated similarity index value of the woody species between the two land use types was $61 \%$. The higher the values of Sorenson coefficient of similarity indicate higher similarity in species composition between the sites and it's vice versa. Thus, the finding indicated that there were high species overlaps between the two land uses. The result was less than the similarity value (75\%) reported by Ebisa (2014), 
between the coffee farms and the adjacent natural forests in western Oromia, Ethiopia.

\section{Diameter class distribution}

To determine the vegetation structure of the study land use type, woody species in different DBH classes was analyzed. The $\mathrm{DBH}$ was classified into fourteen classes with $5 \mathrm{~cm}$ intervals (Figure 1). The highest number of individual woody species per hectare were distributed in the DBH class $(5.0-10 \mathrm{~cm})$ having $1250 \mathrm{ha}^{-1}(64.10 \%)$ in natural forest and $471 \mathrm{ha}^{-1}(72.33 \%)$ in coffee farm. The general patterns of DBH class distribution of the two land use type were showed an inverted J-shaped distribution with a little fluctuation for the higher DBH classes (Figure 1). Similar study was conducted by (Molla and Asfaw, 2014), where the cumulative diameter distribution pattern shown an inverted J-shaped distribution due to highest species frequency in lower class and gradually decreasing in higher class in enset-based coffee agroforestry and adjacent natural forest in Sidama zone, Ethiopia.

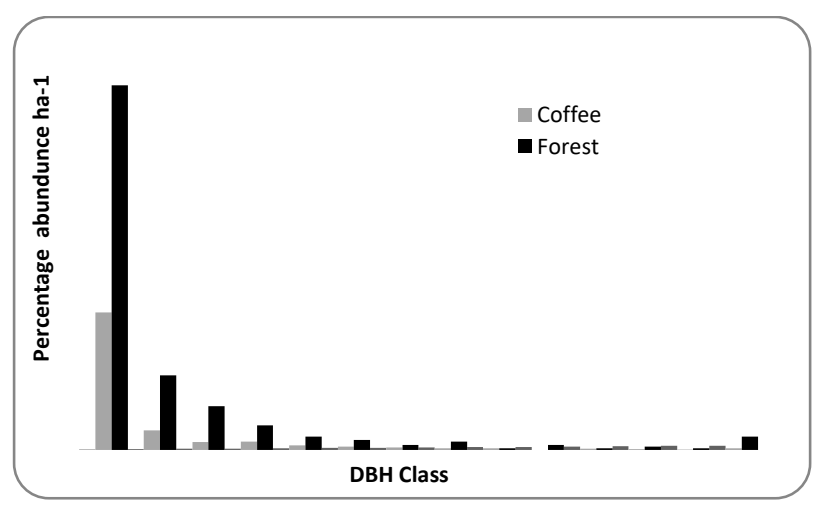

Figure 1: Distribution patterns of woody species by diameter class in the two land use types

Key: DBH class in cm: 1=5 - 10.0; 2=10.1 - 15.0; 3=15.1 - 20.0; 4=20.1 $25.0 ; \mathbf{5}=25.1-30.0 ; \mathbf{6}=30.1-35.0 ; \mathbf{7}=35.1-40.0 ; 8=40.1-45.0 ; \mathbf{9}=45.1-$ $50.0 ; 10=50.1-55.0 ; 11=55.1-60.0 ; 12=65.1-70.0 ; 13=70.1-75.0$; $14>75.0$.

\section{Basal area}

The total basal area was $364.44 \mathrm{~m}^{2} /$ hectare in coffee farms, of which Coffea arabica and Albizia grandibracteata constitutes $61.8 \%\left(225.42 \mathrm{~m}^{2} /\right.$ hectare $)$ and $13.3 \%$ (48.49 $\mathrm{m}^{2} /$ hectare) respectively whereas $669.84 \mathrm{~m}^{2} /$ hectare was recorded in adjacent natural forests. Celtis africana and Albizia grandibracteata were accounted to $51.7 \%$ (346.16 $\mathrm{m}^{2} /$ hectare) and $9.75 \%(65.3$ $\mathrm{m}^{2}$ / hectare) of the results respectively. The present natural forest total basal area was higher than $226.66 \mathrm{~m}^{2} /$ hectare reported in Hudguru Reserve Forest, Karnataka, India (Manohar, 2015) and lower than the average basal area $3181.5 \mathrm{~m}^{2} /$ hectare reported by (Yakob and Fekadu, 2016) in Keja Araba and Tula forests, south west Ethiopia.

\section{Conclusion and Recommendation}

The effects of coffee planting in natural forest on the diversity of the woody species in the case of Yayo biosphere reserve were investigated in this study. Coffee planting in natural forests with intensified management system causes significant differences on the overall woody species diversity i.e. the structure, composition and regeneration rates between the two land use system, where the highest diversity were recorded under natural forests without coffee management. Large number of seedlings and saplings, and whole species diversity per plot were recorded under natural forest without coffee management. The forest with intensified coffee management was highly dominated by coffee which its management activities significantly cause the destruction in the structure and diversity of woody species in the study area. Therefore, it is better to domesticating coffees in home garden and open lands with planting temporal or permanent multipurpose shade trees rather than cultivating it in natural forests.

\section{Acknowledgements}

We are deeply grateful to Mettu University, specifically Bedele Collage of Agriculture and Forestry for the financial support for the success of this research work.

\section{References}

[1]. Ambinakudige, S and Sathish, B., (2009). Comparing tree diversity and composition in coffee farms and sacred forests in the Western Ghats of India. Biodivers Conserv 18:987-1000.

[2]. Azene B., Birnie, A and Tengnäs, B. (1993). Useful trees and shrubs for Ethiopia: Identification, propagation and management for agricultural and pastoral communities. SIDA's regional Soil Conservation Unit. Ethiopia. P. 474

[3]. Ebisa, L. (2014). Diversity of shade tree species in smallholder coffee farms of western Oromia, Ethiopia. African Journal of Geo-Science Research, 3(1).

[4]. Feyera, S and Denich, M. (2006). Effects of wild coffee management on species diversity in the Afromontane rainforests of Ethiopia. Forest Ecology and Management $232,68-74$

[5]. Gordon, C., Manson, R., Sundberg, J and Angon, A. (2007). Biodiversity, profitability, and vegetation structure in Mexican Coffee agro-ecosystem. Agriculture, Ecosystems and Environment 118:256- 266

[6]. Hernandez, R.P., Koohafkan, P and Antoine, J. (2004). Assessing carbon stocks and modeling win-win scenarios of carbon sequestration through land use. Food and Agricultural organization of the United Nations, Rome. Pp 25-120

[7]. Kent, M and Coker, P. (1992). Vegetation Description and Analysis: A Practical Approach. Belhaven Press, 25 Flora Street, London. P. 363

[8]. Kitessa, H., (2015). Effects of Forest Coffee Management Intensification on South West Ethiopian Afromontane Moist Forests, Department of Biology, Jimma University, Ethiopia. Addis Ababa University-Afromontane Mountain 
Research Conference 2015 Mountain research for sustainable livelihoods in a changing world

[9]. Krebs, C. J. 1985. Ecology: The Experimental Analysis of Distribution and Abundance. Harper \& Row Publishers, New York. 800 p.

[10]. Manohar, A. (2015). Study on the Floristic Compositions of Hudguru Reserve Forest, Kodagu District, Karnataka, India. Int.J.Curr.Res.Aca.Rev. 3(9): 34-40

[11]. Senbeta, F and Denich, M. (2006). Effects of wild coffee management on species diversity in the Afromontane rainforests of Ethiopia. Forest Ecology and Management, $232,68 \mathrm{e} 74$
[12].Tadesse, G., Zavaleta, E and Shennan, C. (2014). Coffee landscapes as refugia for native woody biodiversity as forest loss continues in southwest Ethiopia. Biological Conservation, 169, 384-391.

[13]. Tadesse, W., (2003). Vegetation of the Yayo forest in SW Ethiopia: impacts of human use and implications for in situ conservation of wild Coffea arabica L. populations. Cuvillier Verlag Gottingen. Ecological and Development Series No.10

[14].Yakob, G. and Fekadu, A. (2016). Diversity and Regeneration Status of Woody Species: The Case of Keja Araba and Tula Forests, South West Ethiopia. Open Access Library Journal, 3: e2576. http:// dx.doi.org/ 10.4236/oalib.1102576

Appendix 1: Number of species per family of coffee farms and natural forests in Yayo district

\begin{tabular}{|c|c|c|c|c|c|c|c|c|c|}
\hline \multirow{2}{*}{$S / N$} & \multirow{2}{*}{ Family } & \multicolumn{2}{|c|}{$N^{\circ}$ of Species } & \multirow{2}{*}{$\begin{array}{c}N^{\circ} \text { of } \\
\text { Species }\end{array}$} & \multirow{2}{*}{$S / N$} & \multirow{2}{*}{ Family } & \multicolumn{2}{|c|}{$N^{\circ}$ of Species } & \multirow{2}{*}{$\begin{array}{c}N^{\circ} \text { of } \\
\text { Species }\end{array}$} \\
\hline & & $C$ & $F$ & & & & $C$ & $F$ & \\
\hline 1 & Moraceae & 5 & 8 & 9 & 17 & Rutaceae & 2 & 2 & 2 \\
\hline 2 & Fabaceae & 4 & 4 & 5 & 18 & Ulmaceae & 1 & 2 & 2 \\
\hline 3 & Celasteraceae & 3 & 3 & 4 & 19 & Apocynaceae & - & 1 & 1 \\
\hline 4 & Euphorbiaceae & 2 & 2 & 3 & 20 & Araliaceae & 1 & - & 1 \\
\hline 5 & Oleaceae & 1 & 3 & 3 & 21 & Ebenaceae & 1 & 1 & 1 \\
\hline 6 & Sapindaceae & 1 & 3 & 3 & 22 & Icacinaceae & 1 & - & 1 \\
\hline 7 & Acanthaceae & 1 & 2 & 2 & 23 & Lamiaceae & - & 1 & 1 \\
\hline 8 & Asteraceae & 2 & 1 & 2 & 24 & Loganiaceae & - & 1 & 1 \\
\hline 9 & Boraginaceae & 2 & 2 & 2 & 25 & Melianthaeceae & 1 & 1 & 1 \\
\hline 10 & Capparidaceae & - & 2 & 2 & 26 & Oliniaceae & 1 & - & 1 \\
\hline 11 & Combretaceae & - & 2 & 2 & 27 & Ranunculaceae & - & 1 & 1 \\
\hline 12 & Dracaenaceae & 1 & 2 & 2 & 28 & Rhizophoraceae & 1 & 1 & 1 \\
\hline 13 & Meliaceae & 1 & 2 & 2 & 29 & Sapotaceae & - & 1 & 1 \\
\hline 14 & Mimosoideae & 1 & 1 & 2 & 30 & Tiliaceae & 1 & 1 & 1 \\
\hline 15 & Myrsinaceae & 1 & 2 & 2 & 31 & Verbenaceae & 1 & 1 & 1 \\
\hline 16 & Rubiaceae & 2 & 1 & 2 & & Imber of species & 38 & 54 & 64 \\
\hline
\end{tabular}

NB: Land use type: C-coffee farms F- Natural forest 